\title{
Ancient origin of a Western Mediterranean radiation of subterranean beetles
}

\author{
Ignacio Ribera ${ }^{1,2^{*}}$, Javier Fresneda ${ }^{3}$, Ruxandra Bucur ${ }^{4,5}$, Ana Izquierdo ${ }^{1}$, Alfried P Vogler ${ }^{4,5}$, Jose M Salgado ${ }^{6}$, \\ Alexandra Cieslak ${ }^{1}$
}

\begin{abstract}
Background: Cave organisms have been used as models for evolution and biogeography, as their reduced aboveground dispersal produces phylogenetic patterns of area distribution that largely match the geological history of mountain ranges and cave habitats. Most current hypotheses assume that subterranean lineages arose recently from surface dwelling, dispersive close relatives, but for terrestrial organisms there is scant phylogenetic evidence to support this view. We study here with molecular methods the evolutionary history of a highly diverse assemblage of subterranean beetles in the tribe Leptodirini (Coleoptera, Leiodidae, Cholevinae) in the mountain systems of the Western Mediterranean.

Results: Ca. $3.5 \mathrm{~KB}$ of sequence information from five mitochondrial and two nuclear gene fragments was obtained for 57 species of Leptodirini and eight outgroups. Phylogenetic analysis was robust to changes in alignment and reconstruction method and revealed strongly supported clades, each of them restricted to a major mountain system in the Iberian peninsula. A molecular clock calibration of the tree using the separation of the Sardinian microplate (at 33 MY) established a rate of 2.0\% divergence per MY for five mitochondrial genes (4\% for cox 1 alone) and dated the nodes separating the main subterranean lineages before the Early Oligocene. The colonisation of the Pyrenean chain, by a lineage not closely related to those found elsewhere in the Iberian peninsula, began soon after the subterranean habitat became available in the Early Oligocene, and progressed from the periphery to the centre.

Conclusions: Our results suggest that by the Early-Mid Oligocene the main lineages of Western Mediterranean Leptodirini had developed all modifications to the subterranean life and were already present in the main geographical areas in which they are found today. The origin of the currently recognised genera can be dated to the Late Oligocene-Miocene, and their diversification can thus be traced to Miocene ancestors fully adapted to subterranean life, with no evidence of extinct epigean, less modified lineages. The close correspondence of organismal evolution and geological record confirms them as an important study system for historical biogeography and molecular evolution.
\end{abstract}

\section{Background}

Isolated or extreme environments, such as islands or high mountains, have been preferred systems for the study of speciation and processes of adaptation $[1,2]$. One of these "natural laboratories" for evolution is the deep subterranean environment, which combines extreme but homogeneous and constant conditions with a discontinuous distribution promoting isolation $[3,4]$. Despite the early recognition of the potential value of

\footnotetext{
* Correspondence: ignacio.ribera@ibe.upf-csic.es
'Museo Nacional de Ciencias Naturales, José Gutiérrez Abascal 2, 28006

* Correspondence: ignacio.ribera@ibe.upf-csic.es
'Museo Nacional de Ciencias Naturales, José Gutiérrez Abascal 2, 28006 Madrid, Spain
}

(c) 2010 Ribera et al; licensee BioMed Central Ltd. This is an Open Access article distributed under the terms of the Creative Commons Attribution License (http://creativecommons.org/licenses/by/2.0), which permits unrestricted use, distribution, and reproduction in any medium, provided the original work is properly cited.

the subterranean fauna in evolutionary biology (e.g. Darwin devotes three pages of the Origins to discuss the effect of disuse and the convergence among cave species in North America and Europe, [5] pp. 137-139), studies of cave organisms have been hampered by their general scarcity and the difficulty of accessing their habitat.

Most of the evolutionary studies on subterranean fauna have focused on its origin and adaptations [4-6]. Cave or endogean species are characterised by a number of shared characters, assumed to be either caused by loss of function due to "lack of use" (apterism, depigmentation, reduction or complete loss or eyes [5,7]), or 
adaptations to the harsh environmental conditions in caves or deep soil, such as elongated body and appendages, cold adaptation, modified life cycles, modified fat metabolism, or development of sensory organs $[3,6,8]$ (see [9-11] for specific examples of Pyrenean Leptodirini). Subterranean species are usually considered "super specialists", which cannot survive outside the narrow range of highly stable conditions found in their habitats, and have very limited potential to disperse [4]. As a result, the geographical range of subterranean species is usually very restricted, in many cases to a single cave or a karstic system $[8,12]$. Species traditionally considered to have wide distributions had often been shown to be complexes composed of multiple cryptic lineages when molecular methods were applied (e.g. [13,14]).

A widely accepted view on lineage evolution in cave organisms is that subterranean species are evolutionary dead-ends that do not disperse once fully adapted to the environment of deep caves or soil. They are prone to become extinct before being replaced by lineages newly derived from epigean species that re-colonise the subterranean medium $[4,15]$. There are two general hypotheses regarding the origin of the subterranean fauna (see $[4,16,17]$ for reviews): the climatic relict and the habitat shift hypotheses. Briefly, under the climatic relict hypothesis [18] the subterranean medium acts as a refuge for epigean fauna in times of unfavourable climatic conditions. The populations that are forced into a subterranean habitat become isolated from their epigean relatives and eventually develop the morphological and physiological adaptations to this new environment. In lineages with exclusively subterranean species the lack of close epigean relatives is due to extinction of the latter, leaving the subterranean species as the only survivors that escaped extinction [18]. The adaptive shift hypothesis $[19,20]$ surmises that the colonisation of the subterranean medium is driven by the opportunity to exploit new resources. Epigean populations are not forced below ground by changing conditions, and there may be limited genetic flux between the two environments for some time. Both scenarios assume multiple origins of the subterranean lineages from closely related epigean relatives, with recurrent colonisation of the subterranean medium.

There is, however, little phylogenetic evidence to support these hypotheses, especially for the most diverse lineages of exclusively subterranean species, such as some groups of beetles. Among Coleoptera there are multiple examples of phylogenetically independent cave or endogean groups, in particular in the families Carabidae, Staphylinidae and Leiodidae [21,22]. Many of these are either species poor subterranean lineages or a mix of hypogean and epigean species, with different degrees of morphological modifications and ecological specialisation. Only a few groups appear to represent extensive monophyletic radiations of exclusively subterranean species. Among them, the tribe Leptodirini in the family Leiodidae [21] includes at present ca. 240 recognised genera and ca. 1,800 species [23], which are almost exclusively subterranean. The highest diversity is found in the Mediterranean basin, in particular in the north and east of the Iberian peninsula, some Mediterranean islands (Corsica and Sardinia), the southern Alps, Balkan peninsula, Romania and southern Russia, the Caucasus, Middle East and Iran [23]. The few Leptodirini found east of Iran, and the only two Nearctic species (in the genus Platycholeus), are of uncertain phylogenetic affinities ([24,25], see Discussion).

The monophyly of the western Palaearctic Leptodirini is strongly supported by morphological characters [24-26], but their internal phylogeny was only recently addressed with numerical methods, and mostly with morphological analysis of the internal structure of the male genitalia, as other external morphological characters show extreme homoplasy [25] (see Fig. 1 for an overview of the morphological diversity of the group). The resolution and support attained with these character sets is, however, very limited, and was unable to provide a robust phylogenetic framework.

We provide here a comprehensive molecular data set for the main lineages of Leptodirini present in the Western Mediterranean, including the Iberian peninsula (plus adjacent mountain massifs in Southern France) and Sardinia. The known fauna of this region includes ca. 40 genera with some 230 mostly obligatory troglobiontic species, but also some endogean or muscicolous species in the genera Bathysciola and Notidocharis [23] (Additional file 1). We aim to establish a robust phylogeny to study the evolution of this extensive subterranean species radiation, and to provide a temporal framework for the diversification of various lineages and the colonisation of the geographical areas in which they occur.

\section{Methods}

\section{Taxon sampling}

We follow the classification of Lawrence \& Newton [27] and Perreau [23] down to tribe level. All ingroup taxa in the study are currently included in Leiodidae: Cholevinae: Leptodirini, although the formal classification of Leptodirini is in need of a phylogenetic revision [25]. We use here "group of genera" (or "group" for simplicity) for lineages found to be monophyletic in our analyses, to avoid confusion with the traditionally defined "series" which in the French school of mid- $20^{\text {th }}$ century entomology did not necessarily imply monophyly in its modern sense [28]. We sampled representatives of all major lineages present in the Western Mediterranean 


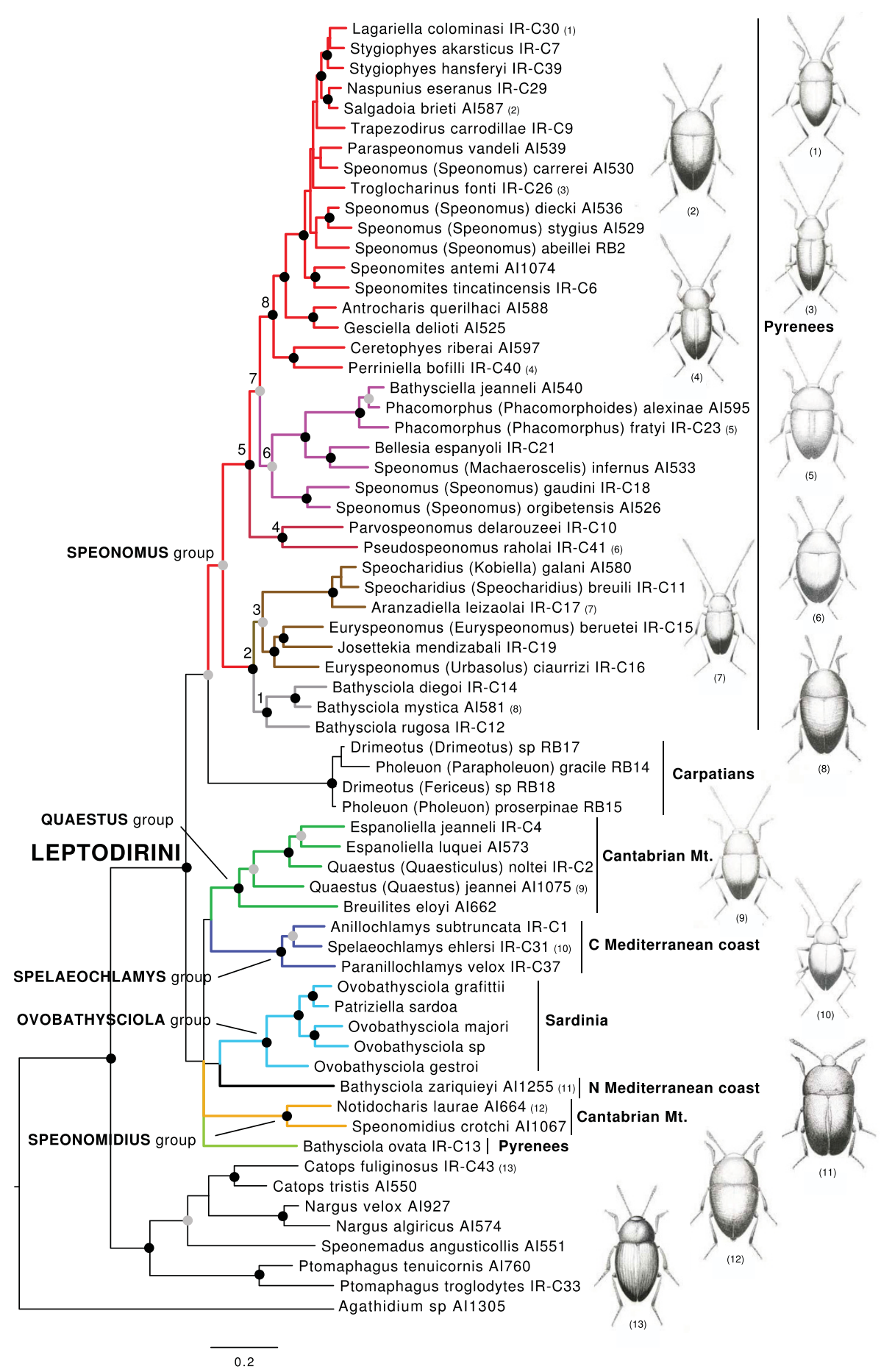

Figure 1 Phylogram obtained with MrBayes with the MAFFT alignment including the Sardinian species, with the geographical area in which the main lineages are distributed (see Fig. 2). Black circles, well supported nodes (Bayesian pp $>0.95$, ML bootstrap $>70 \%$ ) for the four measures (Bayesian in MrBayes, ML in Garli, each for the MAFFT and PRANK alignments). Grey circles, good support in at least two measures, the others at least bootstrap $>50 \%$ or $\mathrm{pp}>0.5$. See Additional file 3 for the detailed values of support, and Fig. 2 for the distribution of the main clades. Habitus of species, from top to down: (1) Lagariella colominasi (Zariquiey), (2) Salgadoia brieti (Jeannel), (3) Troglocharinus kiesenwetteri (Dieck), (4) Perriniella faurai Jeannel, (5) Phacomorphus fratyi (Dupré), (6) Pseudospeonomus raholai (Zariquiey), (7) Aranzadiella leizaolai Español, (8) Bathysciola mystica Fresneda \& Fery, (9) Quaestus arcanus Schauffus, (10) Spelaeochlamys ehlersi Dieck, (11) Bathysciola zariquieyi Bolívar, (12) Notidocharis uhagoni (Sharp), (13) Catops nigricans (Spence). 
(31 out of the 42 genera occurring in the Iberian peninsula), plus the two endemic Sardinian genera using data from [29] and two genera from the Carpathians as examples of Eastern lineages, Drimeotus and Pholeuon [23] (Additional file 1). No Leptodirini are known from the Balearic islands. Sardinia has three additional species currently included in Speonomus subgenus Batinoscelis and four species of Bathysciola, and Corsica five species of Parabathyscia, a genus of the Bathysciola series sensu Perreau [23] with Alpine and Eastern European affinities. Most Western Mediterranean missing genera could readily be associated to clades of the sampled taxa according to the structure of the aedeagus, which we show here to be a character with reliable phylogenetic information (see $[25,30]$ for a detailed taxonomic discussion).

The final data matrix included 57 species of Leptodirini and 8 outgroups from different tribes of Cholevinae (Anemadini, Ptomaphagini, Cholevini; Additional file 1) and Agathidium as a member of the phylogenetically separated subfamily Leiodinae [26,31].

\section{DNA extraction, amplification and sequencing}

The specimens used in the study were preserved in absolute ethanol in the field. A full list of collectors and localities is given in Additional file 1. Extractions of single specimens were non-destructive, using a standard phenol-chloroform method or the DNeasy Tissue Kit (Qiagen GmbH, Hilden, Germany). Vouchers and DNA samples are kept in the collections of the Natural History Museum, London (NHM) and Museo Nacional de Ciencias Naturales, Madrid (MNCN) (Additional file 1).
We amplified fragments of seven genes, five mitochondrial and two nuclear: 3' end of cytochrome c oxidase subunit (cox 1$)$; 5 ' end of the large ribosomal unit plus the Leucine transfer plus the 3' end of NADH dehydrogenase subunit $1(r r n l+\operatorname{trn} L+n a d 1)$; an internal fragment of cytochrome b (cob); 5' end of the small ribosomal unit, $18 \mathrm{~S}$ rRNA $(S S U)$; and an internal fragment of the large ribosomal unit, 28S rRNA $(L S U)$. Primers used are given in Table 1, and PCR protocols are given in $[32,33]$. Sequences were assembled and edited using Sequencher TM 4.1.4 (Gene Codes, Inc., Ann Arbor, MI). New sequences have been deposited in GenBank (NCBI) with Acc. Nos GU356744-GU356993 (Additional file 1). In two cases (Quaestus noltei (Coiffait) and Bathysciola ovata (Kiesenwetter)) the final sequence was a composite of two different specimens of the same species (Additional file 1).

No specimens from Sardinia were available for sequencing, but sequences of the same fragment of the cox1 gene used here (776 overlapping positions) could be obtained for several Sardinian species from GenBank [29]. We excluded sequences reported to be obtained from dry material in [29], as they were placed in unlikely positions in the phylogeny or had large numbers of autapomorphies,

\section{Phylogenetic analyses}

We used two different approaches for multiple progressive pair-wise alignment, either with secondary refinement using the MAFFT online v.6 and the Q-INS-i algorithm [34] ("MF" in the following) or with modelling the evolution of indels with PRANK [35] ("PR").

Table 1 Primers used in the study. F, forward; R, reverse.

\begin{tabular}{|c|c|c|c|c|}
\hline Gene & Name & Sense & Sequence & Reference \\
\hline \multirow[t]{5}{*}{$\operatorname{cox} 1$} & Jerry (M202) & $\mathrm{F}$ & CAACATTTATTITGATTITTGG & [72] \\
\hline & Pat (M70) & $\mathrm{R}$ & TCCA(A)TGCACTAATCTGCCATATTA & [72] \\
\hline & Chy & $\mathrm{F}$ & T(A/T)GTAGCCCA(T/C)TTTCATTA(T/C)GT & A. Cieslak, this work \\
\hline & Tom & $\mathrm{R}$ & AC(A/G)TAATGAAA(A/G)TGGGCTAC(T/A)A & A. Cieslak, this work \\
\hline & Tom-2 & $\mathrm{R}$ & A(A/G)GGGAATCATTGAATAAA(A/T)CC & A. Cieslak, this work \\
\hline \multirow[t]{2}{*}{$c o b$} & CB3 & $\mathrm{F}$ & GAGGAGCAACTGTAATTACTAA & [73] \\
\hline & CB4 & $\mathrm{R}$ & AAAAGAAA(AG)TATCATTCAGGTTGAAT & [73] \\
\hline \multirow[t]{7}{*}{$r r n L-n a d 1$} & $16 \mathrm{saR}(\mathrm{M} 14)$ & $\mathrm{F}$ & CGCCTGTITA(A/T)CAAAAACAT & [72] \\
\hline & $16 \mathrm{Sa}$ & $\mathrm{R}$ & ATGTTITTGTTAAACAGGCG & [72] \\
\hline & $16 \mathrm{Sb}$ & $\mathrm{R}$ & CCGGTCTGAACTCAGATCATGT & [72] \\
\hline & 16SAlf1 & $\mathrm{R}$ & GCATCACAAAAAGGCTGAGG & [74] \\
\hline & ND1A (M223) & $\mathrm{R}$ & GGTCCCTTACGAATTTGAATATATCCT & {$[72]$} \\
\hline & 16Sbi & $\mathrm{F}$ & ACATGATCTGAGTTCAAACCGG & {$[72]$} \\
\hline & FawND1 & $\mathrm{R}$ & TAGAATTAGAAGATCAACCAGC & [72] \\
\hline \multirow[t]{2}{*}{ SSU } & $5^{\prime}$ & $\mathrm{F}$ & GACAACCTGGTTGATCCTGCCAGT & {$[32]$} \\
\hline & b5.0 & $\mathrm{R}$ & TAACCGCAACAACTTTAAT & {$[32]$} \\
\hline \multirow[t]{2}{*}{ LSU } & $\mathrm{Ka}$ & $\mathrm{F}$ & ACACGGACCAAGGAGTCTAGCATG & NHM (2000) \\
\hline & $\mathrm{Kb}$ & $\mathrm{R}$ & CGTCCTGCTGTCTTAAGTTAC & NHM (2000) \\
\hline
\end{tabular}


Bayesian analyses were conducted on a combined data matrix with MrBayes 3.1.2 [36], using six partitions corresponding to the six genes, but combining the short trnL together with the $r r n L$ gene. Evolutionary models were estimated prior to the analysis with ModelTest 3.7 [37]. MrBayes ran for $5 \times 10^{\wedge} 6$ generations using default values, saving trees at each $500^{\text {th }}$ generation. "Burn-in" values were established after visual examination of a plot of the standard deviation of the split frequencies between two simultaneous runs.

We also conducted maximum likelihood searches in Garli v.0.951 http://www.bio.utexas.edu/faculty/antisense/garli/Garli.html, which uses a stochastic genetic algorithm-like approach to simultaneously find the topology, branch lengths and substitution model parameters [38]. We used an estimated GTR $+\mathrm{I}+\Gamma$ model for the combined sequence (as estimated with ModelTest), and the default settings. Support was measured with 1,000 bootstrap replicates, reducing the number of generations without improving the topology necessary to complete each replicate to 5,000 .

\section{Estimation of molecular rates and dates of diversification}

For the age calibration of the phylogenetic tree we used the point of separation between the Sardinian and the continental lineages. The Sardinian clade most likely originated by allopatric separation when the Sardinian microplates split from continental Europe through tectonic movements [29]. Recent tectonic reconstructions $[39,40]$ allow both a detailed geographical analysis of the relative positions of the microplates to the continent and fixing a minimum date for the origin of the Sardinian clade. The tectonic movements leading to the separation of the Western Mediterranean microplates started not before $33 \mathrm{MY}$ ago, and by $25 \mathrm{MY}$ ago the separation from Iberia and the Gulf of Lyon was complete, although some connections with the Italian peninsula may have persisted [40]. However, given the limited dispersal among subterranean populations the geological uncertainty as to the existence of remnant land bridges are likely to be unimportant for the dating of the separation of Leptodirini. The use of a hard bound minimum age calibration of $25 \mathrm{MY}$ as the latest possible population split would bias the estimations towards younger ages [41], so we use the earlier date of $33 \mathrm{MY}$ as the most plausible time of separation between the Sardinian clade and its sister, which may still be conservative (too recent) if the separation of the lineages predated the split of the microplates.

Because available sequences for the species of the Sardinian clade were limited to the cox 1 marker (see above) we conducted the Bayesian tree searches including or excluding the sequences of the Sardinian species, to test for the effect of missing data. The topologies of the resulting trees were identical (see Results). We therefore used the topology obtained with the Bayesian analyses for the whole dataset with the PR alignment (which was fully compatible with that obtained with MF, but more resolved; see below), to apply two methods to obtain an ultrametric tree: Bayesian estimations, as implemented in Beast 1.4.7 [42], and penalized likelihood [43], as implemented in r8s 1.71 http://ginger.ucdavis.edu/r8s/. We used the branch lengths corresponding to the single cox 1 sequence (pruning the species with missing $\operatorname{cox} 1$ from the tree), with a GTR $+\mathrm{I}+\Gamma$ model with parameters estimated in PAUP [44].

For the Bayesian analyses in Beast, well supported nodes in the analyses with the combined mitochondrial and nuclear sequence were constrained to be monophyletic (see Results), and a GTR $+\mathrm{I}+\Gamma$ model was enforced with an uncorrelated lognormal relaxed clock and a Yule diversification model [42]. All parameters were set to default values, with the exception of the prior of the age of the clade formed by the Sardinian species and their sister, which was set to a normal distribution with mean of $33 \mathrm{MY}$ and a standard deviation of 2.0 MY (corresponding to a 95\% confidence interval of 28.8 and $36.3 \mathrm{MY}$ ) to allow for variance from stochastic sampling error of nucleotide changes [41]. The results of two independent runs were merged with Tracer v1.4 and TreeAnnotator v1.4.7 [42].

In r8s we used the Truncated Newton algorithm and performed a cross-validation procedure with smoothing factors between 1 and 500 (after elimination of the outgroups) [43]. Once the optimal smoothing factor was found, the program was run again using $33 \mathrm{MY}$ as a minimum constraint for the node including the Sardinian clade and its sister. A confidence interval of the rates was estimated using the profiling option in $\mathrm{r} 8 \mathrm{~s}$ with the topologies of the last 1,000 trees in one of the MrBayes runs, with branch lengths for coxl estimated in PAUP as above. Note that because the branch lengths are not those originally estimated in MrBayes for the whole combined sequence, but those estimated in PAUP for $\operatorname{cox} 1$ alone, the stochastic variation reflected in the confidence interval is the result of the different topologies of the 1,000 trees used, plus the variation introduced subsequently by rate smoothing in $\mathrm{r} 8 \mathrm{~s}$.

To test for possible artefacts due to the inclusion of only the $\operatorname{cox} 1$ sequence, and to obtain a rate calibration for other mitochondrial genes, we performed additional analyses in Beast including all the mitochondrial sequences but excluding the Sardinian species. The node below that of the insertion of the Sardinian species was constrained to have the age estimated with $\operatorname{cox} 1$ alone, with a normal distribution with standard deviation of $2.0 \mathrm{MY}$. Beast was run for $5 \times 10^{\wedge} 6$ generations, saving trees at every 500th generation. 


\section{Results}

\section{Phylogeny of Western Mediterranean Leptodirini}

The protein-coding genes (cox1, cob, nad1) had no indels, with the single exception of a three to four nucleotide insertion beyond the end of the $\operatorname{cox} 1$ gene (in the region of the trnL) in the Quaestus group of genera and in Aranzadiella. Most of the length variation was concentrated in the hypervariable regions of the $L S U$ fragment, while for the $r r n L$ and $S S U$ genes the length variation between the two alignment methods used (MF and PR) was relatively small (Table 2). For the $L S U$ gene the PR alignment was more than 1,000 positions longer than the MF alignment, with a loss of 79 informative characters (Table 2). Despite the large differences in the length of the combined sequence between the two alignment methods (mostly due to $L S U$ ), the changes in the topology or level of support of the resulting trees were negligible (see below).

The optimal evolutionary model was GTR $+\mathrm{I}+\Gamma$, both for the combined data and the individual gene fragments. The two independent Bayesian runs reached values of the standard deviation of the split frequencies between them of ca. 0.005 for both the PR and MF alignments. The estimated parameters for the two alignments were within the $95 \%$ confidence intervals of each other, with the single exception of alpha $(\alpha)$ of the SSU and $L S U$ partitions, and the probability of invariant sites (I) of the LSU partition (Additional file 2). The topologies of the trees obtained with Bayesian probabilities for the two alignments and those obtained with ML in Garli were either identical or compatible with each other (i.e. consensus consistent with resolved nodes). The differences in tree topology only affected the relationships of one of the outgroups (Speonemadus angusticollis Kraatz) and the internal phylogenetic relationships of the Carpathian clade (Fig. 1, Additional file 3). Nodal support was generally high, with most posterior probability values $>0.95$ and maximum likelihood boostratp values $>70 \%$ (Additional files 3,4 ), with generally higher support values at some deeper nodes with

\begin{tabular}{|c|c|c|c|c|c|c|}
\hline \multirow[b]{2}{*}{ gene } & \multicolumn{2}{|c|}{ Raw length } & \multicolumn{2}{|c|}{ MAFFT } & \multicolumn{2}{|c|}{ PRANK } \\
\hline & $\min$ & $\max$ & No. & Inf. & No. & Inf. \\
\hline $\operatorname{cox} 1$ & 826 & 830 & 830 & 380 & 830 & 380 \\
\hline$r r n L+t r n L$ & 668 & 705 & 727 & 248 & 756 & 257 \\
\hline nadl & 378 & 378 & 378 & 176 & 378 & 176 \\
\hline$c o b$ & 358 & 358 & 358 & 176 & 358 & 176 \\
\hline SSU & 591 & 606 & 647 & 69 & 612 & 56 \\
\hline LSU & 579 & 774 & 923 & 252 & 2141 & 173 \\
\hline
\end{tabular}

Bayesian methods (Additional file 3), as had been observed in other studies [45].

The exclusion of the Sardinian species (due to missing data, see Methods) in a Bayesian analysis using the MF alignment produced a topology identical to that obtained with all species (Additional file 4).

All species of Leptodirini formed a well supported clade, to the exclusion of other tribes of Cholevinae (Fig. 1). Within the Leptodirini, well supported major lineages were composed of species restricted to particular biogeographical regions (Figs 1, 2). In most cases the main lineages were fully allopatric, as separate clades were confined to the Pyrenees (Speonomus group of genera), the Cantabrian Mountains (Quaestus and Speonomidius groups), the central Mediterranean coast of Iberia (Spelaeochlamys group), Sardinia (Ovobathysciola group), and the Carpathians. In addition, two species of Bathysciola, B. zariquieyi Bolívar distributed throughout the coastal mountain systems in Catalonia [46] and $B$. ovata, with a wide distribution in Pyrenees and SE France, constitute phylogenetically isolated lineages separated from other members of the genus (Figs 1,2).

The monophyletic Pyrenean lineage, corresponding to the Speonomus series of Fresneda et al. [25], was sister to the genera from the Carpathians (Fig. 1), and was split in two main lineages defined by nodes 2 and 5 in Fig. 1 . The former includes genera from the lower western areas (node 3, Basque Country and Navarra) plus some endogean and muscicolous Bathysciola with a wider distribution towards the east. The clade defined by node 5 includes genera from the eastern lowland areas (node 4, Parvospeonomus and Pseudospeonomus) plus a large clade of genera from the central Pyrenees (node 7). The latter clade was also geographically structured, with genera roughly distributed west (node 6) and east (node 8) of the river Gállego in the central Pyrenees (Figs 1, 2). The genus Troglocharinus (included in node 8) has a disjunct distribution, with some species distributed in the southern coastal ranges of Catalonia (Fig. 2b; [30]), although the monophyly of the genus could not be tested as the southern species were missing from our study.

The remaining Leptodirini consisted of several highly supported clades with very well defined distributions: (1) the Quaestus group in the Cantabrian mountains; (2) the Spelaeochlamys group in the Mediterranean coast of Spain; (3) the Ovobathysciola group in Sardinia; (4) the divergent species Bathysciola zariquieyi from the Catalonian mountains; (5) the Speonomidius group of Cantabria; and (6) Bathysciola ovata from the Pyrenees (Figs 1, 2a). The relationships among these lineages were in general poorly resolved, although the sister relationship between the Quaestus and Spelaeochlamys groups, and of Bathysciola zariquieyi and the Sardinian 


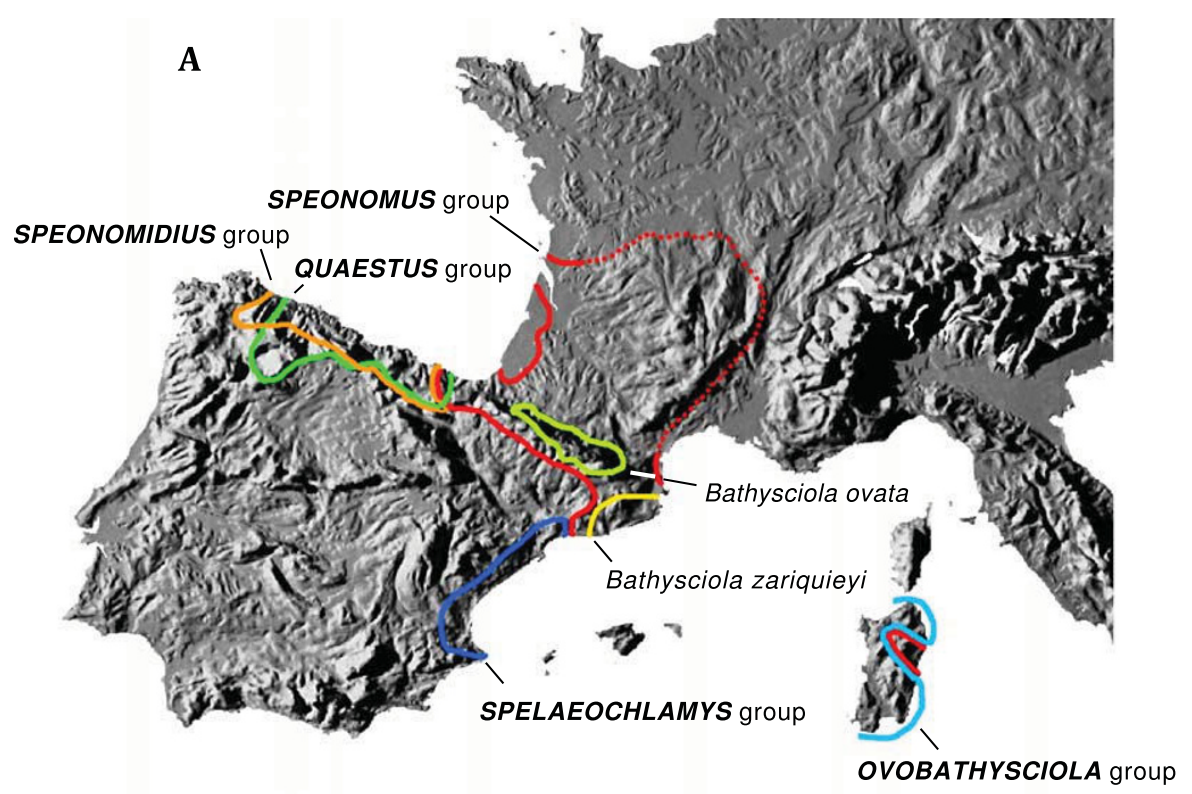

B

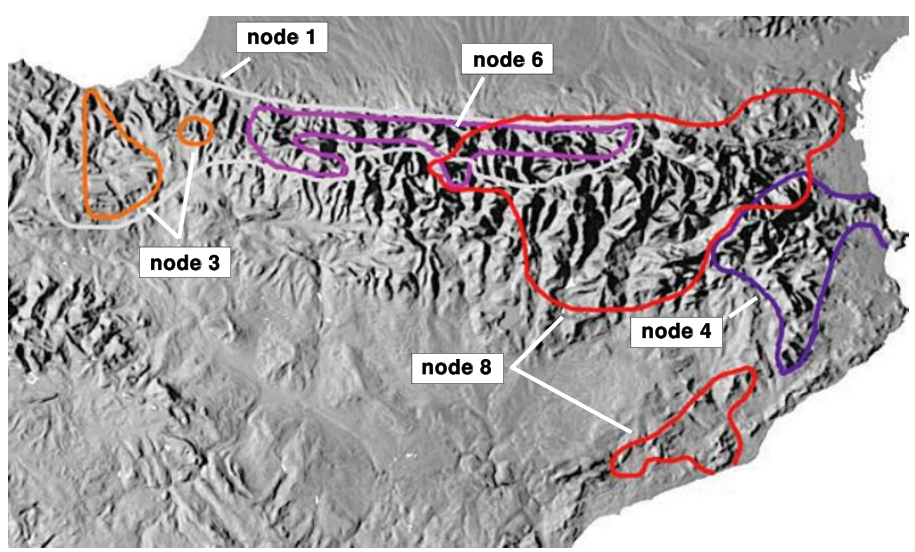

Figure 2 Distribution of the main lineages of W Mediterranean Leptodirini as established in this study. (a), General distribution of the main lineages (see Fig. 1); (b) detailed distribution of the Speonomus group of genera in the Pyrenees (see Fig. 1).

clade, were well supported in some Bayesian analyses (Additional file 3).

\section{Temporal diversification of the Western Mediterranean Leptodirini}

The split between the Sardinian clade and its mainland sister Bathysciola zariquieyi was used for estimating the evolutionary rate of cox1, using a calibration point of 33 MY ago as the time of vicariant separation of both lineages (Fig. 1). When using Beast, the rate estimate was $0.020+/-0.005$ substitutions per site per MY, i.e. an overall pair-wise divergence of $4.0 \%$ per MY (Table
3, Additional file 5). The node that grouped B. zariquieyi plus the Sardinian clade with their sisters was estimated to date back to ca. $38+/-7 \mathrm{MY}$ ago. This constraint was subsequently used for the estimation of the evolutionary rate for the combined mitochondrial genes (excluding the species of the Sardinian clade for which these data were missing). The rate of the five combined mitochondrial markers (cox1, rrnL, trnL, nad1 and $c o b$, comprising 2,293 bp in the MF alignment; Table 2) was $0.010+/-0.002$, equivalent to an overall pair wise divergence of $2.0 \%$ per MY (Table 3 ). The estimation of node ages using the combined mitochondrial 
Table 3 Estimated rates of molecular evolution and ages of the constricted nodes, with confidence intervals.

\begin{tabular}{|c|c|c|c|c|c|c|c|c|c|c|}
\hline & & \multicolumn{3}{|c|}{ Beast, mitochondrial } & \multicolumn{3}{|c|}{ Beast, cox 1} & \multicolumn{3}{|c|}{$\mathrm{r} 8 \mathrm{~s}, \operatorname{cox} 1$} \\
\hline & & mean & lower & upper & mean & lower & upper & mean & lower & upper \\
\hline & Rate & 0.0099 & 0.0081 & 0.0116 & 0.0204 & 0.0151 & 0.0260 & 0.0115 & 0.0113 & 0.0117 \\
\hline 1 & root & 44.16 & 37.46 & 50.76 & 45.41 & 35.87 & 56.03 & 39.62 & . & . \\
\hline 2 & Sardinian clade [cox1] & n.a. & n.a. & n.a. & 32.75 & 28.96 & 36.76 & 33.00 & . & . \\
\hline 3 & Sardinian clade $[\mathrm{mt}]$ & 37.79 & 33.86 & 41.84 & 37.92 & 31.43 & 45.43 & 36.92 & . & . \\
\hline 4 & infraflagellates & 41.18 & 35.60 & 46.82 & 41.42 & 33.04 & 50.28 & 36.92 & 20.69 & 39.09 \\
\hline 5 & Speonomus group & 33.61 & 27.67 & 39.82 & 36.32 & 27.53 & 46.23 & 30.45 & 22.81 & 32.50 \\
\hline 6 & Speonomidius group & 18.51 & 13.70 & 23.69 & 22.67 & 14.37 & 31.31 & 20.70 & & \\
\hline 7 & Spelaeochlamys group & 15.04 & 11.31 & 18.98 & 13.63 & 9.08 & 18.32 & 15.97 & & \\
\hline 8 & Quaestus group & 29.20 & 24.06 & 34.37 & 30.54 & 23.03 & 37.94 & 31.11 & . & . \\
\hline 9 & node 1 & 17.59 & 13.39 & 22.12 & 17.56 & 11.00 & 24.23 & 18.02 & . & \\
\hline 10 & node 2 & 24.16 & 19.47 & 29.12 & 23.59 & 17.29 & 30.58 & 21.88 & & \\
\hline 11 & node 3 & 22.59 & 18.03 & 27.23 & 22.41 & 16.46 & 29.04 & 21.88 & . & . \\
\hline 12 & node 4 & 19.40 & 14.64 & 24.47 & 22.34 & 14.69 & 30.32 & 20.80 & . & . \\
\hline 13 & node 5 & 27.94 & 22.95 & 33.34 & 31.46 & 23.39 & 39.90 & 26.94 & . & . \\
\hline 14 & node 6 & 21.18 & 17.06 & 25.63 & 23.29 & 17.00 & 29.94 & 21.24 & . & . \\
\hline 15 & node 7 & 25.08 & 20.71 & 29.89 & 26.95 & 20.28 & 34.18 & 25.08 & . & . \\
\hline 16 & node 8 & 21.22 & 17.28 & 25.37 & 21.44 & 16.06 & 27.29 & 19.63 & . & . \\
\hline 17 & Aranzadiella+Speocharidius & 10.09 & 7.39 & 12.89 & 8.99 & 5.81 & 12.52 & 9.85 & & \\
\hline 18 & Euryspeonomus+Josettekia & 18.27 & 14.20 & 22.89 & 18.07 & 12.62 & 24.29 & 18.92 & . & . \\
\hline 19 & Phacomorphus-Bellesia & 16.18 & 12.76 & 19.75 & 16.70 & 11.83 & 21.73 & 15.84 & & \\
\hline 20 & Phacomorphus & 5.70 & 4.11 & 7.37 & 5.71 & 3.63 & 7.88 & 4.83 & & \\
\hline 21 & Perriniella+Ceretophyes & 14.72 & 10.86 & 18.65 & 17.93 & 12.00 & 24.12 & 17.37 & . & . \\
\hline 22 & Gesciella-Antrocharis & 9.45 & 6.56 & 12.42 & 12.11 & 7.32 & 17.08 & 13.72 & . & . \\
\hline 23 & Speonomites & 9.96 & 7.36 & 12.65 & 9.61 & 6.25 & 13.16 & 9.49 & . & . \\
\hline 24 & Gesciella-Stygiophyes & 18.38 & 14.92 & 22.17 & 19.74 & 14.69 & 25.36 & 18.95 & . & . \\
\hline 25 & Speonomites-Stygiophyes & 13.06 & 10.55 & 15.63 & 12.48 & 9.28 & 15.96 & 12.26 & . & . \\
\hline 26 & Stygiophyes-Speonomus & 11.71 & 9.52 & 14.04 & 11.21 & 8.32 & 14.32 & 11.67 & . & . \\
\hline 27 & Speonomus & 9.85 & 7.68 & 12.11 & 9.69 & 6.96 & 12.67 & 10.37 & & \\
\hline 28 & Stygiophyes-Troglocharinus & 10.70 & 8.67 & 12.83 & 9.76 & 7.14 & 12.49 & 10.59 & . & . \\
\hline 29 & Stygiophyes-Salgadoia & 7.85 & 6.18 & 9.59 & 7.67 & 5.46 & 10.11 & 8.61 & & \\
\hline 30 & Stygiophyes+Lagariella & 5.63 & 4.32 & 7.10 & 5.55 & 3.70 & 7.48 & 6.48 & & \\
\hline
\end{tabular}

See Fig. 3 \& Additional file 5 for the definition of the nodes. In bold, nodes used for the calibration (see Methods).

markers was very similar to that obtained using $\operatorname{cox} 1$ only, and fully within the $95 \%$ confidence interval of each other (Table 3, Fig. 3, Additional files 3, 6).

For comparison we estimated the age of the nodes with the Penalized Likelihood (PL) method in r8s [43], using cox 1 only and a calibration date of 33 MY for the Sardinian-continental split. Estimated node ages throughout were very similar to those obtained with Bayesian methods, and well within their $95 \%$ confidence interval, with the sole exception of the node defining the sister relationship between Antrocharis and Gesciella (older with the PL estimation; Table 3 and Additional file 6). However, the estimated overall rate was $0.0115+/-0.0005(2.3 \%$ per MY, Table 3), i.e. lower than the estimate obtained with Beast for the $\operatorname{cox} 1$ gene, suggesting substantial differences in the branch length estimates from both methods.
The main lineages of Western Mediterranean Leptodirini were estimated to have diversified between ca. 45$33 \mathrm{MY}$, during the Mid to Late Eocene (Fig. 3). The relative age of the nodes suggests that by the time the Sardinian lineage formed (presumably by Late Eocene Early Oligocene) all other main lineages were already present and distributed over their present geographical areas. All lineages with a well defined geographical distribution were estimated to have originated by the Late Oligocene (Figs 2,3). The age of diversification within the genera for which more than one species was sequenced ranged from ca. 20 to 5 MY (mostly Miocene), disregarding some cases where the currently recognised genera were found to be paraphyletic (Euryspeonomus, Quaestus) or polyphyletic (Speonomus, Bathysciola) (Fig. 1). 


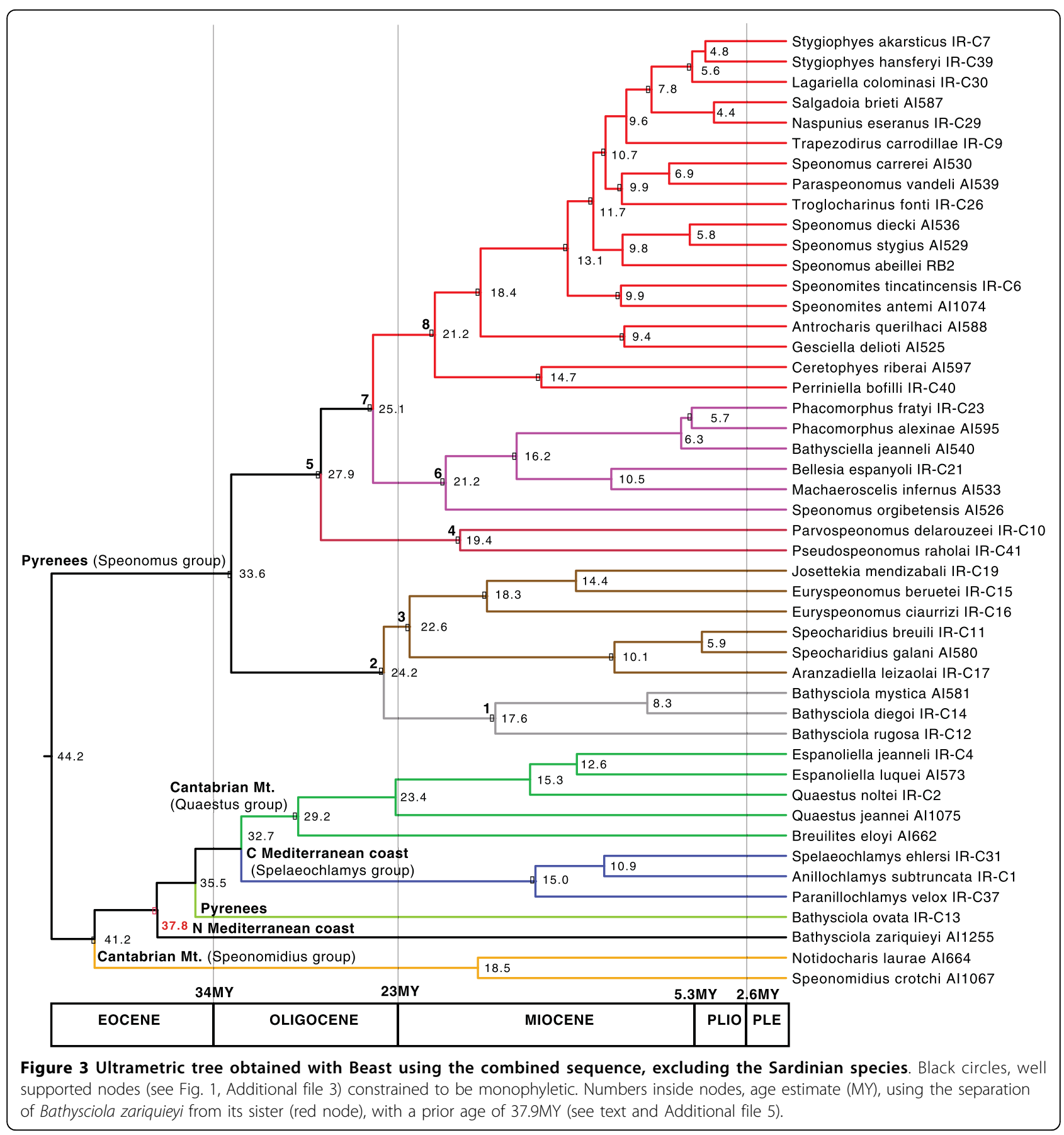

\section{Discussion}

The most prominent feature of the phylogeny of the Western Mediterranean Leptodirini is the strong geographical division among the main lineages. Support for these geographically restricted clades is generally very strong and stable to changes in alignment or reconstruction methods, while the relationships among them is less well supported. All well supported deep clades were restricted to a single mountain massif, and each of these is occupied by a single clade with the sole exceptions of the Cantabrian mountains, with two separate lineages (the Quaestus and Speonomidius groups of genera) and some species of Bathysciola in the Pyrenees. In both cases one of these sympatric lineages is composed of cave species only (Quaestus and Speonomus groups) while the other is muscicolous or endogean (Speonomidius and Bathysciola for the Cantabrian mountains and the Pyrenees respectively) (see Additional file 1 for the 
habitat of the studied species). It would be interesting to compare the rates of diversification of the different lineages in the same geographical area, and the occurrence of species in sympatry to test for the possible effect of competitive exclusion within each habitat type.

\section{Phylogeny of Western Mediterranean Leptodirini}

Our results basically agree with the traditional taxonomic division of Leptodirini in "infraflagellates" [25] and "supraflagellates" $[8,28]$, based on the complex structure that is characteristic of the aedeagus in the former (the "Y piece" [25]). In our study the infraflagellates correspond to the Pyrenean and the Carpathian species, albeit supported only in the Bayesian inference and with the exclusion of some species of Bathysciola. The polyphyly of the genus Bathysciola has already been established (see [25]), but the inclusion of some species among the "supraflagellates" implies multiple independent origins of a complex aedeagus. Alternatively, the presence of the "Y piece" could be the ancestral condition of Leptodirini, which underwent repeated simplifications in at least the Cantabrian and Sardinian species of the Ovobathysciola group (Fig. 1), contrary to expectations (e.g. $[8,26,28])$.

Our results also support most of the traditional "phyletic series" of Jeannel $[8,28]$, while in Fresneda et al.'s [25] study using characters of the external morphology and the internal genitalia, support was found only for the monophyly of the Speonomus (including Bathysciola) and Spelaeochlamys plus Ovobathysciola series. The molecular analyses also supported the traditionally defined Speonomidius, Quaestus and Spelaeochlamys series [30,47-49]. The Speonomidius series includes the genus Notidocharis [47], with seven muscicolous rather than subterranean species, all with reduced eyes (Additional file 1). Other muscicolous oculated Leptodirini include some Bathysciola-like taxa in Anatolia, the Caucasus and north Iran, plus Adelopsella bosnica (Reitter) from the Balkans and two Nearctic species in the genus Platycholeus [50]. The genera Adelopsella, Platycholeus and Sciaphyes (tribe Sciaphyini from east Siberia [23]) share some unique characters not present in the remaining Leptodirini [8], which suggests they may not be closely related. According to Fresneda et al. [25] the presence of eyes placed Notidocharis as sister to the rest of studied Leptodirini. In the current analysis this position is not strongly contradicted, as the support of the basal nodes of Leptodirini in the trees obtained with ML was very weak (Fig. 1, Additional file 3).

The Pyrenean clade corresponds to the Speonomus series as defined by Fresneda et al. [25] with the exclusion of some species of Bathysciola, but confirming the inclusion of the genus Pseudospeonomus (= Pseudochlamys Comas), distributed in the extreme east of the
Pyrenees and previously grouped with species in the mountains of the Mediterranean coast of Spain [25]. The Sardinian species of the Ovobathysciola group, although grouped with the Mediterranean species (Spelaeochlamys group) in studies of morphology [25,29], seem more closely related to Bathysciola zariquieyi according to the DNA data. The support for this relationship was low under ML, possibly due to missing data (only the $\operatorname{cox} 1$ sequence was available for the Sardinian clade [29]), but reasonably high with Bayesian methods (pp > 0.9 for both the MF and PR alignments). Bathysciola zariquieyi has a relatively wide distribution in the Catalonian coast, from south of Barcelona to the province of Girona [46]. The Catalonia-Sardinia link is more in agreement with geological reconstructions [40], according to which the Sardinian microplates were last connected to the mainland in the north (French coast), rather than the south Iberian Mediterranean coast, as previously assumed [29].

According to our results the Leptodirini fauna of the Iberian peninsula is most likely not monophyletic. The Pyrenean clade seems most closely related to some Eastern European lineages, and the lineage of the Mediterranean coast (Spelaeochlamys group of genera) is related to the Sardinian Ovobathysciola group and to some species north of the Ebro basin and in southern France.

\section{Calibration}

The use of molecular data to estimate the ages of extant taxa has revolutionised many aspects of evolutionary biology [51,52], despite their known limitations and shortcomings [51,53]. There is, however, a great scarcity of good reference calibrations for many groups, and the "standard" arthropod mitochondrial rate of $2.3 \%$ per MY [54] is often used uncritically for a variety of genes, ages and organisms. Subterranean species have been used to calibrate molecular phylogenies, as their distributions presumably are more likely to reflect ancient vicariant events due to their low dispersal (e.g. [29]). However, these ancient vicariant scenarios could be confounded by occasional dispersal of minute endogean species, or in lineages where above-ground dispersal of epigean forms preceded the shift to the subterranean environment. Our calibrations depend on the vicariance between the Sardinian and the European plates, i.e. the presence of a common ancestor in this region prior to the split of these landmasses. Strictly, we cannot exclude an independent origin of subterranean habits in the Sardinian Ovobathysciola group, or drifting of a Bathysciola-like endogean ancestor to the island subsequent to its separation from the continent, but these seem to be unlikely scenarios. Using this calibration point, the average rate for the sequenced mitochondrial genes ( $\operatorname{cox} 1$, $c y b, r r n L$ and $n a d 1)$ was $2 \%$ per MY, surprisingly close 
to the standard $2.3 \%$ [54], and in agreement with results from other calibrations for beetles [12,55-57]. The cox 1 gene alone produces a twofold faster rate $(4 \%)$ compared to the averaged mitochondrial rate including the slower $r r n L$ and $\operatorname{trn} L$ genes, also in agreement with previous results (e.g. [58,59]). The age estimations using Beast and r8s, whether using cox 1 or the combination of several protein coding and ribosomal mitochondrial genes, were remarkably similar (Table 3 , Additional file 6), despite differences in the estimation of the rate for the cox 1 gene between r8s and Beast. As noted above, this may be related to the differences in the method used for the computation of the branch lengths (Bayesian methods in Beast, penalized likelihood in $\mathrm{r} 8 \mathrm{~s}$ $[42,43])$.

\section{Evolution of the Western Mediterranean Leptodirini}

The estimations of node ages date the origin of the main lineages of Leptodirini to the Early Eocene, with the initial diversification taking place during the Oligocene (ca. 35-20 MY, Fig. 3). Our sampling does not include some lineages of Leptodirini including genera from the Alps, Balkans or mainland Italy, but these are mostly "infraflagellates", [26,28], i.e. likely to be embedded in the existing clades. Due to the finding of the Carpathian as sister to the Pyrenean lineage, and the inclusion in our dataset of the oculated, muscicolous Notidocharis, it is unlikely that these missing lineages could move the origin of the lineages further back in time.

The diversification of the main lineages during the Paleogene coincides with the closure of the Tethys Sea and the collision of the Iberian and Eurasian plates [39]. Under this scenario, the origin of the Pyrenean lineage of Leptodirini at $34+/-6 \mathrm{MY}$ ago followed shortly upon the formation of the Pyrenees during the Alpine orogeny which was largely completed by the Early Oligocene $[60,61]$. The colonisation of the Pyrenean subterranean medium therefore took place without delay after suitable habitat was available, i.e. after the karstification by water erosion of the recently raised calcareous massifs. This view is strengthened by the fact that the basal cladogenetic splits involve the species at both edges of the chain (nodes 2 and 4 in Fig. 3, see Fig. 2b), with subsequent splits including species more centrally distributed (node 6, plus Ceretophyes and Perriniella), and the species in the central part, with the highest elevations, among the most recently derived lineages (node 8 ). This centripetal early colonisation, completed ca. 10+/- $3 \mathrm{MY}$ ago (Fig. 3), was followed in some cases by an intra-genus diversification in each of the valleys or mountain massifs to which these groups are currently confined. The origin of the main lineages of Leptodirini in the Cantabrian mountains and the Mediterranean coast appears slightly older than in the
Pyrenees. This is in agreement with a likely older age of the available habitat, as these mountain areas were present in the Iberian plate before the formation of the Pyrenees [39]. The Oligocene to mid Miocene origin of the main lineages (above what is currently recognized at the level of genus) is older than for other lineages of subterranean European fauna whose origin was placed in the Late Miocene to Pleistocene $([62,63]$ and references therein), including the Pyrenean radiation of subterranean Trechini groundbeetles [22].

The strong geographical structure of subterranean taxa at multiple hierarchical levels is a common pattern also evident in other recent studies (see e.g. [64,65] for Crustacea; or [12,22] for Coleoptera). Each well defined biogeographical unit is occupied by a single monophyletic lineage, while any phylogenetic substructure within such groups frequently reflects the geographical subdivision of these wider areas, in many cases contrary to expectations from morphological similarities. In some cases these geographically confined lineages include both subterranean and epigean species, e.g. stygobiontic Crustacea [66,67], spiders and beetles in the tribe Trechini in the Canary Islands $[56,68]$, or stygobiontic diving beetles in Australia [12]. These examples provide strong evidence for multiple colonisation of the subterranean medium, as they include lineages that exhibit different degrees of morphological modifications. Their adaptations to the subterranean environment is in accordance with the adaptive shift hypothesis [19], that invokes multiple independent colonisations of the subterranean medium and continued survival of the epigean ancestors (see Introduction). In the Western Mediterranean Leptodirini, the only lineage with non-subterranean, oculated muscicolous species (Notidocharis) is placed in an ambiguous position close to the origin of the western Mediterranean lineages, i.e. has been separated from the troglobitic lineages for more than $40 \mathrm{MY}$ ago. All other major lineages, with Oligocene or Early Miocene origin, include only anophthalmous, endogean, interstitial or cave species (Additional file 1). This pattern strongly suggests that each of the geographical lineages diversified after the colonization of the subterranean medium took place, as suggested for other terrestrial $[15,22,69,70]$ and stygobiontic [71] groups. This is in disagreement with both the climatic relict and the adaptive shift hypotheses, which assume multiple colonisations of the subterranean medium by closely related epigean ancestors and perceive the troglobitic taxa as evolutionary dead ends $[18,20]$.

\section{Conclusions}

We have shown here that the main lineages of Western Mediterranean Leptodirini have an origin in the EarlyMid Oligocene, and most likely developed all 
modifications to the subterranean life in the main geographical areas in which they are found today prior to the Late Oligocene-Miocene. The diversification within each of these main geographical areas seems thus to have taken place since early Miocene from ancestors fully adapted to the subterranean medium, contrary to most current assumptions about the evolution of the subterranean fauna.

Additional file 1: Specimens used in the study, with locality, collector, voucher reference numbers and accession numbers for the sequences. In grey, specimens combined in a composite sequence.

Click here for file

[http://www.biomedcentral.com/content/supplementary/1471-2148-1029-S1.XLS ]

Additional file 2: Estimation of the parameters for the Bayesian analyses. Click here for file

[http://www.biomedcentral.com/content/supplementary/1471-2148-1029-S2.XLS]

Additional file 3: Cladogram obtained with MrBayes with the MAFFT alignment including the Sardinian species, with detailed node support values. Upper row, MrBayes posterior probabilities, MF/PR; lower row, bootstrap support values (1,000 replicas) in Garli, MF/PR.

Click here for file

[http://www.biomedcentral.com/content/supplementary/1471-2148-1029-S3.PDF ]

Additional file 4: Phylogram obtained with MrBayes with the MAFFT alignment, with the exclusion of the Sardinian species.

Click here for file

[http://www.biomedcentral.com/content/supplementary/1471-2148-1029-S4.PDF ]

Additional file 5: Ultrametric tree obtained with Beast using the cox 1 sequence only, including the Sardinian species (red clade). Black circles, well supported nodes (see Fig. 1, Additional file 3) constrained to be monophyletic. Numbers inside nodes, age estimate (MY) using the separation of the Sardinian species with a prior age of 33MY (see text). Click here for file

[http://www.biomedcentral.com/content/supplementary/1471-2148-1029-S5.PDF ]

Additional file 6: Age estimations of the nodes in Fig. 3 and Additional file 5. Vertical axis, estimated age (MY). Horizontal axis, nodes. White circles, estimation using the combined mitochondrial genes (cox1, rrnL + trnL, nad1, cob) in Beast, with 95\% confidence intervals (dashed lines) (Fig. 3). Black circles, estimation using only cox 1 in Beast, with $95 \%$ confidence interval (solid line) (Additional file 5). Red circles, estimation using the gen cox1 in r8s. Estimations using cox 1 alone were calibrated with the node "Sardinian clade [cox1]", and those using the combined mtDNA with the node "Sardinian clade [mt]". Note than in the estimation using the combined mtDNA genes the Sardinian species were not included.

Click here for file

[http://www.biomedcentral.com/content/supplementary/1471-2148-1029-S6.PDF]

\section{Acknowledgements}

We particularly thank V. Assing, M. Baena, C. Bourdeau, A. Castro, Ph. Déliot, F. Fadrique, A. Faille, C. Hernando and I. Zabalegui for sending material for study. We also thank X. Bellés, C. Bourdeau, A. Casale, A. Faille and C. Hernando for multiple discussions and comments on the systematics and evolution of the subterranean fauna, and Fauna Ibérica for permission to reproduce some of the habitus drawings in Fig. 1. The comments of three Referees helped to improve an earlier version of the manuscript. This work has been funded by NERC grants to APV (lab work at the NHM) and projects CGL2006-11403 and CGL2007-61943 to AC.

\section{Author details}

'Museo Nacional de Ciencias Naturales, José Gutiérrez Abascal 2, 28006 Madrid, Spain. ${ }^{2}$ Institute of Evolutionary Biology (CSIC-UPF), Passeig Maritim de la Barceloneta 37-49, 08003 Barcelona, Spain. ${ }^{3}$ Ca de Massa, E-25526 Llesp, Lleida, Spain. ${ }^{4}$ Natural History Museum, Cromwell Road, London SW7 5BD, UK. ${ }^{5}$ Imperial College London, Silwood Park Campus, Ascot SL5 7PY, UK. ${ }^{6}$ Departamento de Biología Animal, Facultad de Biología, Universidad de León, León, Spain.

\section{Authors' contributions}

IR, AC and JF designed the study. JF and JMS obtained and identified the material. IR, RB, Al and AC did the molecular work and obtained the sequence data. IR did the phylogenetic analyses. IR and AC wrote a first draft, which final version was completed by IR, AC, APV, JF and JMS. All authors read and approved the final manuscript.

Received: 14 September 2009

Accepted: 28 January 2010 Published: 28 January 2010

\section{References}

1. Schluter D: The ecology of adaptive radiations. Oxford, UK: Oxford University Press 2000.

2. Coyne J, Orr HA: Speciation. Sunderland, MA: Sinauer Associates 2004

3. Vandel A: La biologie des animaux cavernicoles. Paris: Gauthier-Villars 1964.

4. Culver DC, Pipan T: The Biology of Caves and Other Subterranean Habitats. Oxford, UK: Oxford University Press 2009.

5. Darwin C: The Origin of Species. London: John Murray 1859

6. Culver DC: Cave Life: Evolution and Ecology. Cambridge, MA: Harvard University Press 1982.

7. Lamarck JB: Philosophie zoologique, ou exposition des considérations relatives à l'histoire naturelle des animaux. Paris: Museum d'Histoire Naturelle, Paris 1809, 1.

8. Jeannel R: Monographie des Bathysciinae. Arch Zool exp gen, Paris 1924, 63:1-436.

9. Deleurance $\mathrm{S}$ : Recherches sur les Coléoptères troglobies de la sousfamille des Bathysciinae. Ann Sci nat, Paris (Zool) ser 12 1963, 1(5):1-172.

10. Delay B: Milieu souterrain et ecophysiologie de la reproduction et du developpement des coléoptères Bathysciinae hypoges. Mém Biospél 1978, 1-349.

11. Corbiere-Tichane G, Loftus R: Antennal thermal receptors of the cave beetle, Speophyes lucidulus Delar. 2. Cold receptor response to slowly changing temperature. J Comp Physiol 1983, 153(3):343-351.

12. Leys R, Watts CHS, Cooper SJB, Humphreys WF: Evolution of subterranean diving beetles (Coleoptera: Dytiscidae: Hydroporini, Bidessini) in the arid zone of Australia. Evolution 2003, 57:2819-2834.

13. Trontelj P, Douady CJ, Fiser C, Gibert J, Goricki S, Lefebure T, Sket B, Zaksek V: A molecular test for cryptic diversity in ground water: how large are the ranges of macro-stygobionts?. Freshw Biol 2009, 54:727-744

14. Zaksek V, Sket B, Gottstein S, Franjevic D, Trontelj P: The limits of cryptic diversity in groundwater: phylogeography of the cave shrimp Troglocaris anophthalmus (Crustacea: Decapoda: Atyidae). Mol Ecol 2009, 18:931-946.

15. Barr TC, Holsinger JR: Speciation in cave faunas. Annu Rev Ecol Syst 1985, 16:313-337.

16. Desutter-Grandcolas L, Grandcolas P: The evolution towards troglobitic life: a phylogenetic reappraisal of climatic relict and local habitat shift hypothesis. Mém Biospéol 1996, 23:57-63.

17. Belles X: Survival, opportunism and convenience in the processes of cave colonization by terrestrial faunas. Oecol Aquat 1992, 10(1991):325-335

18. Peck SB, Finston TL: Galapagos islands troglobits: the question of tropical troglobits, parapatric distributions and eyed sister-species, and their origin by parapatric speciation. Mém Biospél 1993, 20:19-37.

19. Howarth F: The Zoogeography of specialized cave animals: a bioclimatic model. Evolution 1980, 34:394-406.

20. Howarth F: The evolution of non-relictual tropical troglobites. Int I Speleol 1987, 16:1-16

21. Decu V, Juberthie C: Coléoptères (généralités et synthèse). Encyclopædia Biospeologica II Société de BiospéologieJuberthie C, Decu V 1998, II: $1025-1030$ 
22. Faille A, Ribera I, Deharveng L, Bourdeau C, Garnery L, Quéinnec E, Deuve T: A molecular phylogeny shows the single origin of the Pyrenean subterranean Trechini ground beetles (Coleoptera: Carabidae). Mol Phylogen Evol 2010, 54:97-106.

23. Perreau M: Catalogue des Coléoptères Leiodidae et Platypsyllinae. Mém Soc ent Fr 2000, 4:1-460.

24. Newton AF: Phylogenetic problems, current classification and generic catalog of world Leiodidae (including Cholevidae). Phylogeny and evolution of subterranean and endogean Cholevidae (= Leiodidae, Cholevinae) Proceedings of XX International Congress of Entomology, Firenze, 1996 Torino: Atti Museo Regionale di Scienze NaturaliGiachino PM, Peck SB 1998, 41-178.

25. Fresneda J, Salgado JM, Ribera I: Phylogeny of western Mediterranean Leptodirini, with an emphasis on genital characters (Coleoptera: Leiodidae: Cholevinae). Syst Ent 2007, 32:332-358.

26. Giachino PM, Vailati D, Casale A: Major questions in the phylogeny and biogeography of Cholevidae (Coleoptera), with emphasis on the subfamily Leptodirinae. Phylogeny and evolution of subterranean and endogean Cholevidae (= Leiodidae, Cholevinae) Proceedings of XX International Congress of Entomology, Firenze, 1996 Torino: Atti Museo Regionale di Scienze NaturaliGiachino PM, Peck SB 1998, 179-209.

27. Lawrence JF, Newton AF: Families and subfamilies of Coleoptera (with selected genera, notes, references and data on family-group names). Biology, phylogeny, and classification of coleoptera: papers celebrating the 80th birthay of Roy A Crowson Varsovia: Museum i Instytut Zoologii PANPakaluk J, Slipinski SA 1995, 779-1006.

28. Jeannel $R$ : La genèse des faunes terrestres. Eléments de biogéographie. Paris: Presses Universitaires de France 1942.

29. Caccone A, Sbordoni V: Molecular biogeography of cave life: A study using mitochondrial DNA from Bathysciine beetles. Evolution 2001, 55:122-130.

30. Salgado JM, Blas M, Fresneda J: Fauna Iberica. Vol. 31: Coleoptera: Cholevidae. Madrid: CSIC 2008

31. Newton AF: Leiodidae Fleming, 1821. Handbook of Zoology Vol IV, Arthropoda: Insecta; Coleoptera, Vol I, Morphology and Systematics (Archostemata, Adephaga, Myxophaga, Polyphaga partim) Berlin, New York: De GruyterBeutel RG, Leschen RAB 2005, 261-280.

32. Shull VL, Vogler AP, Baker MD, Maddison DR, Hammond PM: Sequence alignment of $18 \mathrm{~S}$ ribosomal RNA and the basal relationships of Adephagan beetles: evidence for monophyly of aquatic families and the placement of Trachypachidae. Syst Biol 2001, 50:945-969.

33. Ribera I, Beutel RG, Balke M, Vogler AP: Discovery of Aspidytidae, a new family of aquatic Coleoptera. Proc R Soc Lond B 2002, 269(1507):2351-2356.

34. Katoh K, Toh H: Recent developments in the MAFFT multiple sequence alignment program. Brief Bioinform 2008, 9:286-298.

35. Loytynoja A, Goldman N: An algorithm for progressive multiple alignment of sequences with insertions. Proc Natl Acad Sci USA 2005, 102:10557-10562.

36. Huelsenbeck JP, Ronquist F: MRBAYES: Bayesian inference of phylogenetic trees. Bioinformatics 2001, 17:754-755.

37. Posada D, Crandall KA: MODELTEST: testing the model of DNA substitution. Bioinformatics 1998, 14:817-818.

38. Zwickl D: Genetic algorithm approaches for the phylogenetic analysis of large biological sequence datasets under the maximum likelihood criterion. Austin: Texas 2006.

39. Rosenbaum G, Lister GS, Duboz C: Relative motions of Africa, Iberia and Europe during Alpine orogeny. Tectonophysics 2002, 359:117-129.

40. Schettino A, Turco E: Plate kinematics of the Western Mediterranean region during the Oligocene and Early Miocene. Geophys J Int 2006, 166:1398-1423.

41. Ho S, Phillips M: Accounting for calibration uncertainty in phylogenetic estimation of evolutionary divergence times. Syst Biol 2009, 58:367-380.

42. Drummond A, Rambaut A: BEAST: Bayesian evolutionary analysis by sampling trees. BMC Evol Biol 2007, 7:214.

43. Sanderson MJ: Estimating absolute rates of molecular evolution and divergence times: a penalized likelihood approach. Mol Biol Evol 2002, 19:101-109.

44. Swofford DL: PAUP*: Phylogenetic Analysis Using Parsimony (* and Other Methods) Version 4. Sunderland, MA.: Sinauer Associates 2002
45. Erixon P, Svennblad B, Britton T, Oxelman B: Reliability of Bayesian posterior probabilities and bootstrap frequencies in phylogenetics. Syst Biol 2003, 52:665-673.

46. Fresneda J, Salgado JM: The genus Bathysciola Jeannel, 1910 in the Iberian Peninsula and Pyrenees. Taxonomic revision of the sections IV, VI and VII (Jeannel, 1924) (Coleoptera, Cholevidae, Leptodirinae). Graellsia 2006, 62:45-54

47. Salgado JM: A new revision and taxonomic position for the Cantabrian Leptodirini: sections Quaestus and Speonomidius (Coleoptera: Cholevidae). Ann Soc ent Fr (NS) 2000, 36:45-59.

48. Salgado JM, Fresneda J: Revision of the section Anillochlamys Jeannel, 1909 (Coleoptera: Leiodidae: Cholevinae: Leptodirini). Ann Soc ent Fr (NS) 2003, 39:361-384.

49. Bellés X, Comas J, Escolà O, Español F: Los Bathysciinae ibéricos, propuesta de ordenación taxonómica (Col. Catopidae). Speleon 1978, 24:59-68.

50. Zoia S, Rampini M: Leptodirinae del Caucaso e dell'Iran settentrionale (Coleoptera Cholevidae). Rev suisse Zool 1994, 101:771-827.

51. Bromham L, Penny D: The modern molecular clock. Nat Rev Genet 2003, 4:216-224.

52. Donoghue PCJ, Benton MJ: Rocks and clocks: calibrating the Tree of Life using fossils and molecules. Trends Ecol Evol 2007, 22:424-431.

53. Pulquerio MJF, Nichols RA: Dates from the molecular clock: how wrong can we be?. Trends Ecol Evol 2007, 22:180-184

54. Brower AVZ: Rapid morphological radiation and convergence among races of the butterfly Heliconius erato inferred from patterns of mitochondrial-DNA evolution. Proc Natl Acad Sci USA 1994, 91(14):6491-6495.

55. Pons J, Barraclough TG, Gomez-Zurita J, Cardoso A, Duran DP, Hazell S, Kamoun S, Sumlin WD, Vogler AP: Sequence-based species delimitation for the DNA taxonomy of undescribed insects. Syst Biol 2006, 55:595-609.

56. Contreras-Díaz HG, Moya O, Oromí P, Juan C: Evolution and diversification of the forest and hypogean ground-beetle genus Trechus in the Canary Islands. Mol Phylogenet Evol 2007, 42:687-699.

57. Balke M, Ribera I, Hendrich L, Miller MA, Sagata K, Posman A, Vogler AP Meier R: New Guinea highland origin of a widespread arthropod supertramp. Proc R Soc Lond B 2009, 276:2359-2367.

58. Ribera I, Hernando C, Aguilera P: Agabus alexandrae sp. n. from Morocco, with a molecular phylogeny of the Western Mediterranean species of the A. guttatus group (Coleoptera: Dytiscidae). Ins Syst Evol 2001, 32:253-262.

59. Trewick SA, Wallis GP: Bridging the 'beech-gap': invertebrate phylogeography implicates recent rather than ancient processes in New Zealand biogeographic patterns. Evolution 2001, 55:2170-2180.

60. Casas Sainz AM, Faccenna C: Tertiary compressional deformation of the Iberian plate. Terra Nova 2001, 13:281-288.

61. Barnolas A, Pujalte V: La cordillera Pirenaica. Geología de España Madrid: SGE-IGMEVera J 2004, 233-241.

62. Trontelj P: The age of subterranean crayfish species. A comment on Buhay \& Crandall (2005): subterranean phylogeography of freshwater crayfishes shows extensive gene flow and surprisingly large population sizes. Mol Ecol 2007, 16:2841-2843.

63. Trontelj P, Goricki S, Polak S, Verovnik R, Zaksek V, Sket B: Age estimates for some subterranean taxa and lineages in the Dinaric Karst. Time in Karst Meeting: March 2007; Postojna, Slovenia 2007, 18:3-189.

64. Fiser C, Sket B, Trontelj P: A phylogenetic perspective on 160 years of troubled taxonomy of Niphargus (Crustacea: Amphipoda). Zool Scr 2008, 37:665-680.

65. Foulquier A, Malard F, Lefebure T, Gibert J, Douady CJ: The imprint of Quaternary glaciers on the present-day distribution of the obligate groundwater amphipod Niphargus virei (Niphargidae). J Biogeogr 2008, 35:552-564.

66. Villacorta $C$, Jaume $D$, Oromí $P$, Juan C: Under the volcano: phylogeography and evolution of the cave-dwelling Palmorchestia hypogaea (Amphipoda, Crustacea) at La Palma (Canary Islands). BMC Biol 2008, 6.

67. Carlini DB, Manning J, Sullivan PG, Fong DW: Molecular genetic variation and population structure in morphologically differentiated cave and surface populations of the freshwater amphipod Gammarus minus. Mol Ecol 2009, 18:1932-1945. 
68. Arnedo MA, Ferrández MA: Mitochondrial markers reveal deep population subdivision in the European protected spider Macrothele calpeiana (Walckenaer, 1805) (Araneae, Hexathelidae). Conserv Genet 2007, 8:1147-1162.

69. Barr TC: A Synopsis of the cave beetles of the genus Pseudanophthalmus of the Mitchell Plain in Southern Indiana (Coleoptera, Carabidae). Am Mid Nat 1960, 63:307-320.

70. Christman M, Culver D, Madden M, White D: Patterns of endemism of the eastern North American cave fauna. J Biogeogr 2005, 32:1441-1452.

71. Buhay JE, Crandall KA: Subterranean phylogeography of freshwater crayfishes shows extensive gene flow and surprisingly large population sizes. Mol Ecol 2005, 14:4259-4273.

72. Simon C, Frati F, Beckenbach A, Crespi B, Liu H, Flook P: Evolution, weighting, and phylogenetic utility of mitochondrial gene-sequences and a compilation of conserved polymerase chain-reaction primers. Ann ent Soc Am 1994, 87:651-701.

73. Barraclough TG, Hogan JE, Vogler AP: Testing whether ecological factors promote cladogenesis in a group of tiger beetles (Coleoptera: Cicindelidae). Proc R Soc Lond B 1999, 266(1423):1061-1067.

74. Vogler AP, Desalle R, Assmann T, Knisley CB, Schultz TD: Molecular population genetics of the endangered tiger beetle Cicindela dorsalis (Coleoptera, Cicindelidae). Ann ent Soc Am 1993, 86:142-152.

doi:10.1186/1471-2148-10-29

Cite this article as: Ribera et al:: Ancient origin of a Western

Mediterranean radiation of subterranean beetles. BMC Evolutionary

Biology 2010 10:29.

\section{Submit your next manuscript to BioMed Central and take full advantage of:}

- Convenient online submission

- Thorough peer review

- No space constraints or color figure charges

- Immediate publication on acceptance

- Inclusion in PubMed, CAS, Scopus and Google Scholar

- Research which is freely available for redistribution

Submit your manuscript at www.biomedcentral.com/submit 